\title{
Budaya organisasi sebagai pemoderasi pengaruh antara asimetri informasi, ketaatan aturan akuntansi, dan kesesuaian kompensasi terhadap kecenderungan kecurangan akuntansi (Studi empiris pada OPD Kabupaten Indragiri Hulu)
}

\author{
Alfiati Silfi $^{1^{*}}$, Nita Wahyuni $^{2}$ \\ ${ }^{1,2}$ Fakultas Ekonomi dan Bisnis Universitas Riau \\ *Correspondent email : alfiatisilfi@gmail.com
}

\begin{abstract}
This study aims to examaine the effect of Organizational Culture as moderated variable for influencing the relationship among Asymetri Information, Complience with Accounting Rules, the Suitability Compensation toward accounting fraud.The sample used in this study is there are agencies in Indargiri Hulu. Collecting data through a questionnaire survey method.The data analysis used multiple regression analysis with SPSS. The result showed that Asymetri Information has significant effect to Accounting Fraud. But the othervariables like compliance with accounting rules, suitable compensation did not influence the accounting fraud. The moderated analysis shows that there was no significant effect of Organization Culture to moderate the relationship between Asymetri Information, Complience with Accounting rules, Suitable Compensation toward Accounting Fraud.
\end{abstract}

Keywords: Organizational Culture; Asymetri Information; Complience with Accounting Rules; Suitable Compensation; Accounting Fraud

\section{PENDAHULUAN}

Kecurangan atau fraud merupakan suatu tindakan yang menyimpang dilakukan seseorang atau organissai untuk memperoleh keuntungan pribadi, kelompok ataupun organisasi. Kecurangan dapat dilakukan pada segala tingkatan yang ada dalam organisasi, baik pada sector swasta maupun sector public seperti instansi pemerintahan. Nugrayati (2016) menyatakan bahwa kecurangan pada istansi pemerintahan dapat terjadi karena organisasi tersebut memiliki struktur yang cukup kompleks, system birokrasi yang berbelit, integrasi lingungan kerja yang rendah, kontrol yang tidak efektif dan tekanan yang tinggi.

Kecurangan Laporan Keuangan meliputi tindakan yang dilakukan oleh pejabat atau eksekutif suatu perusahaan atau instansi pemerintah untuk menutupi kondisi keuangan yang sebenarnya dengan melakukan rekayasa keuangan dalam penyajian laporan keuangan untuk memperoleh keuntungan. Korupsi merupakan jenis kecurangan yang paling sulit dideteksi karena menyangkut kerja sama dengan pihak lain seperti suap dan korupsi, di mana hal ini merupakan jenis yang terbanyak yang terjadi di negara-negara berkembang yang penegakan hukumnya lemah dan masih kurang kesadaran akan tata kelola yang baik sehingga faktor integritasnya masih dipertanyakan ( Bartenputra, 2016).

Menurut Transparancy Internationalll (2011) Kecenderungan kecurangan akuntansi dalam laporan keuangan pemerintahan, salah satunya yaitu kecurangan dalam pelaksanaan anggaran. Penelitian Indonesia Corruption Watch (ICW) pada semester II periode 1 Juli sampai 31 Desember 2010 menunjukkan peningkatan jumlah kasus korupsi mencapai 272 kasus. Pada semester pertama tahun 2010, BPS mencatat bahwa korupsi pada sektor keuangan daerah berada di peringkat paling atas dengan $38 \%$. Secara faktual, Indonesia termasuk negara dengan peringkat korupsi yang tinggi di dunia, yaituperingkat 100 dari 183 terkorup dengan indeks korupsi 3,0.

Kecenderungan Kecurangan Akuntansi (KKA) atau fraud di Indonesia marak terjadi akhir-akhir ini, dimana hal tersebut menjadi pusat perhatian berbagai media di Indonesia maupun di dunia. Terjadinya kecenderungan kecurangan akuntansi membuat organisasi atau lembaga menjadi rugi.Kecurangan atau fraud merupakan suatu kesalahan yang dilakukan secara sengaja. Dalam lingkup akuntansi konsep 
kecurangan atau fraud merupakan penyimpangan dari prosedur akuntansi yang harusnya ditetapkan dalam suatu entitas, penyimangan tersebut akan berdampak pada laporan keuangan.

Berdasarkan Riauterkini (RENGAT) Menyikapi penetapan sekda inhu sebagai tersangka korupsi sisa anggaran 2011 sebesar Rp.2,7 miliar. Sekda Inhu menegaskan fungsi Sekda hanya administrasi, untuk masalah keuangan bendahara yang lebih mengetahui. Penegasan Sekda Inhu ini disampaikan melalui selulernya Senin (19/1/15) menyikapi penetapan dirinya sebagai tersangka dugaan korupsi sisa anggaran APBD Inhu sebesar Rp.2,7 miliar, walau dirinya belum begitu mengetahui apa yang disangkakan. karena belum melihat langsung surat panggilan.

Kecurangan telah terjadi di Kabupaten Indragiri Hulu, provinsi Riau.kecurangan yang terjadi adalah kasus korupsi yang melibatkan sekda Inhu. Penyidik kejaksaan Negeri Rengat telah menetapkan sekda inhu.Sebagai tersangka kasus dugaan korupsi sisa Anggaran APBD Inhu sebesar Rp 2,7 Miliar. Penetapan status tersangka terhadap sekda Inhu ini disampaikan langsung oleh Kejari Rengat Teuku Rahman kepada sejumlah wartawan dalam acara press briefing target capaian Kejaksaan Negeri Rengat tahun 2015 (Riauterkini).

Kecurangan yang dilakukan oleh individu ataupun orga nisasi muncul karena faktor-faktor tertentu yang memungkinkan terjadinya tindakan kecurangan, diantaranya : Asimentri Informasi, Ketaatan aturan akuntansi, dan kesesuaian kompensasi,

Menurut Kusumastuti (2012) asimetri informasi (information asymmetry) yaitu suatu kondisi di mana ada ketidakseimbangan perolehan informasi antara pihak manajemen sebagai penyedia informasi (prepaper) dengan pihak pemegang saham dan stakeholder pada umumnya sebagai pengguna informasi (user). Hasil penelitian yang dilakukan oleh bartenputra (2016) menemukan bahwa asimetri informasi berpengaruh terhadap kecenderungan kecurangan akuntansi. Hasil penelitian tersebut juga sejalan dengan penelitian Aranta (2013) yang menemukan bahwa asimetri informasi berpengaruh terhadap kecenderungan kecurangan akuntansi. Sedangkan Rahmawati (2012) menemukan bahwa asimetri informasi tidak berpengaruh terhadap kecenderungan kecurangan akuntansi.

Kemudian faktor ketaatan aturan akuntansi juga berkaitan dengan kecenderungan kecurangan akuntansi. Ketaatan aturan akuntansi dipandang sebagai tingkat kesesuaian prosedur pengelolaan aset organisasi, pelaksanaan prosedur akuntansi, dan penyajian laporan keuangan beserta semua bukti pendukungnya, dengan aturan yang ditentukan oleh BPK dan/atau SAP (PP RI Nomor 24/2005). Suatu instansi atau lembaga akan melakukan tindakan kecurangan karena mereka tidak berpedoman pada aturan akuntansi yang berlaku.

Adrian bartenputra (2016), Rahmawati (2012), Ni Putu Sri Widiutami dkk (2017) menemukan dalam penelitiannya bahwa ketaatan aturan akuntansi berpengaruh terhadap kecenderungan kecurangan akuntansi. Dengan demikian dapat disimpulkan bahwa semakin tinggi, ketaatan terhadap aturan suatu organisasi, maka kecenderungan kecurangan yang mungkin terjadi juga akan semakin rendah, sebaliknya jika aturan tersebut diindahkan maka peluang terjadinya kecurangan akan semakin besar. Sedangkan Devy ervina dkk (2016) menemukan bahwa ketaatan aturan akuntansi tidak berpengaruh terhadap kecenderungan kecurangan akuntansi.

Kesesuaian kompensasi juga merupakan faktor yang beraitan dengan kecenderungan kecuragan akuntansi. kesesuaian kompensasi.Fauzi (2011) kesesuaian kompensasi juga merupakan salah satu faktor yang mempengaruhi perilaku tidak etis dan kecenderungan kecurangan akuntansi.Dengan kompensasi yang sesuai, perilaku tidak etis dan kecenderungan akuntansi diharapkan dapat berkurang.Individu diharapkan telah mendapatkan kepuasan dari kompensasi dan tidak melakukan perilaku yang tidak etis serta kecenderungan berlaku curang dalam akuntansi demi memaksimalkan keuntungan pribadi.

Pemberian kompensasi dapat dilihat dari dua komponen yaitu kompensasi langsung dan tidak langsung.Kompensasi langsung terdiri dari gaji, upah, dan insentif. Sedangkan kompensasi tidak langsung dapat berupa asuransi tenaga kerja, tunjangan dan uang pensiun (Rivai 2011)

Beberapa penelitian mengenai kesesuaian kompensasi terhadap kecenderungan kecurangan akuntansi seperti yang dilakukan Rahmahyanti (2017) yang menyatakan bahwa kesesuaian kompensasi berpengaruh terhadap kecenderungan kecurangan akuntansi. Pemberian kompensasi terhadap karyawan dapat mengarah kepada perlakuan yang tidak semestinya terhadap kas.Seorang karyawan yang memiliki masalah keuangan bisa menyalahgunakan kas atau uang yang ada di tangannya. Jika seseorang mempersepsikan bahwa terdapat ketidakadilan mengenai gaji atau kompensasi yang seharusnya didapatkan maka akan mendorong orang tersebut melakukan kecurangan. Hasil penelitian tersebut sejalan dengan penelitian yang dilakukan oleh Devi Ervina dkk (2016) bahwa kesesuaian kompensasi berpengaruh terhadap kecenderungan kecurangan akuntansi.

Namun kedua hasil penelitian tersebut tidak sejalan dengan penelitian yang dilakukan oleh bartenputra (2016) yang menemukan bahwa kesesuaian kompensasi tidak berpengaruh terhadap kecenderungan kecurangan akuntansi.Pemberian kompensasi sebaiknya disesuaikan dengan tingkat 
pekerjaan dan kebutuhan pegawai. Jika kompensasi yang diberikan rendah dan tidak sesuai dengan kesulitan dalam pekerjaan maka akan timbul sikap rasinalisasi dimana pelaku merasa wajar melakukan kecurangan dengan alasan tingkat kesulitan pekerjaanya.

Penelitian ini merupakan pengembangan dari rahmahyanti (201)7, yang meneliti tentang pengaruh sistem pengendalian intenal,kesesuaian kompensasi dan asimetri informasi terhadap kecenderungan kecurangan akuntansi dan menggabungkannya dengan devi ervina dkk (2016) dan bartenputra (2016) dengan menggunakan variabel kesesuaian kompensasi dan ketaatan aturan akuntansi.kemudian penelitian ini ditambah lagi dengan memasukkan satu variabel lain yaitu budaya etis organisasi yang diteliti oleh Aisah Fachrunisa (2015). Namun berbeda dengan tiga penelitian tersebut, bahwa dalam penelitan ini menggunakan variabel budaya etis organisasi sebagai pemoderasi dari asimetri informasi, ketaatan aturan akuntansi dan kesesuaian kompensasi terhadap kecenderungan kecurangan akuntansi. Selain itu terdapat perbedaan lain penelitian ini dengan penelitian sebelumnya adalah lokasi dan tahun penelitian. Untuk objek penelitian ini, peneliti memilih pemerintah kabupaten Indragiri Hulu , dengan alasan kasus yang terjadi di Kabupaten Indragiri Hulu.

Tujuan dari penelitian ini untuk menguji apakah asimetri informasi, ketaatan aturan akuntansi dan kesesuaian kompensasi berpengaruh terhadap kecenderungan kecurangan akuntansi. Untuk menguji apakah asimetri informasi, ketaatan aturan akuntansi dan kesesuaian kompensasi berpengaruh terhadap kecenderungan kecurangan akuntansi dengan dimoderasi Budaya etis organisasi.

\section{METODE PENELITIAN}

\section{Populasi}

Populasi dalam penelitian ini adalah Organisasi Perangkat Daerah yang ada di Pemerintah Kabupaten Indragiri Hulu. Berdasarkan data dari Badan Kepegawaian Daerah (BKD) Kabupaten Indragiri Hulu jumlah Organisasi Perangkat Daerah (OPD) yang terdapat di Kabupaten Indragiri Hulu berjumlah 30 OPD yang terdiri dari Dinas, Badan, Kantor, Sekda dan Inspektorat.

\section{Sampel}

Sampel adalah bagian dari jumlah dan karakteristik yang dimiliki oleh populasi tersebut.Sampel yang diambil dari populasi tersebut harus bersifat representative atau mewakili keseluruhan populasi (Sugiyono, 2014).

Untuk menentukan sampel yang akan digunakan dalam penelitian, perlu adanya teknik sampling yang tepat seperti yang dikemukakan oleh Sugiyono (2014) bahwa Teknik Sampling merupakan teknik pengambilan sampel. Menurut Sugiyono (2001) teknik ini digunakan bila populasi mempunyai anggota/unsur yang tidak homogen dan berstrata secara proporsional. Penelitian ini menggunakan proportionate stratified random sampling .

Adapun kriteria yang ditetapkan adalah pegawai yang bekerja dibagian keuangan dan staff akuntansi di seluruh OPD yang ada di pemerintah kabupaten Indargiri Hulu. Berdasarkan kriteria dari responden yang dijelaskan diatas, maka jumlah sampel yang digunakan dalam penelitian ini sebanyak 90 responden yang terdiri dari 1 orang kabag keuangan dan 2 orang staf akuntansi pada 30 OPD Kabupaten Indragiri Hulu.

\section{Jenis dan Sumber Data}

Jenis dan sumber data yang digunakan dalam penelitian ini yaitu data primer.Data primer yaitu data yang diperoleh langsung terhadap objek penelitian berupa kuesioner yang ditujukan kepada OPD kabupaten Indragiri Hulu.

Penelitian ini menggunakan metode survey. Metode survey yaitu metode penelitian yang dilakukan pada populasi besar maupun kecil, tetapi data yang dipelajari adalah data dari sampel yang diambil dari populasi tersebut, sehingga ditemukan kejadian-kejadian relative, distribusi, dan hubunganhubungan antara variabel sosiologis maupun psikologis (Sugiono, 2012).Metode survey dilakukan dengan menyebarkan kuesioner mengenai variabel yang diuji dalam penelitian ini yaitu pengaruh sistem pengendalian internal, kesesuaian kompensasi, asimetri informasi, ketaatan aturan akuntansi, moralitas individu dan budaya etis oraganisasi terhadap kecenderungan kecurangan akuntansi pada OPD kabupaten Indragiri Hulu. 


\section{Variabel Dependen}

Variabel dependen (terikat) merupakan variabel yang menjadi perhatian utama peneliti Sekarang.Dalam penelitian ini yang menjadi variabel dependen adalah Kecenderungan Kecurangan Akuntansi (Y).

\section{Kecenderungan Kecurangan Akuntansi (Y)}

Dalam penelitian ini variabel yang digunakan adalah Kecenderungan Kecurangan Akuntansi, Dalam Kamus Besar Bahasa Indonesia (KBBI), Kecenderungan mempunyai arti kecondongan (hati) atau kesudian atau keinginan (kesukaan).Kecurangan (fraud) dapat diartikan sebagai bentuk penipuan yang sengaja dilakukan sehingga dapat menimbulkan kerugian tanpa disadari oleh pihak yang dirugikan tersebut dan memberikan keuntungan bagi pelaku (Alison 2006).

\section{Variabel Independen}

Variabel independen sering juga disebut dengan variabel bebas atau variabel tidak terikat. Variabel bebas adalah variabel yang dapat mempengaruhi variabel lain. Variabel independen dalam penelitian ini adalah Sistem Pengendalian Internal (X1), Kesesuaian Kompensasi (X2), Asimetri Informasi (X3), Ketaatan Aturan Akuntansi (X4), Moralitas Individu (X5) dan Budaya Etis Organisasi (X6).

\section{Asimetri Informasi (X3)}

Asimetri Informasi menurut Anthony dan Govindrajan (2001), menyatakan bahwa kondisi asimetri informasi muncul dalam teori keagenan (agency theory), yaitu principal (pemilik/atasan) memberikan wewenang kepada agen (manajer/bawahan) untuk mengatur perusahaan yang dimilikinya. Pendelegasian wewenang akan menyebabkan manajer sebagai pengelola perusahaan akan lebih mengetahui prospek dan informasi perusahaan sehingga menimbulkan ketidak seimbangan informasi antara manajer dengan pemilik yang disebut dengan asimetri informasi.

\section{Ketaatan Aturan Akuntansi (X4)}

Ketaatan terhadap aturan akuntansi merupakan suatu kewajiban dalam organisasi karena apabila laporan keuangan yang dibuat tidak sesuai atau tanpa mengikuti aturan akuntansi yang berlaku maka keadaan tersebut dapat menumbuhkan perilaku tidak etis dan memicu terjadinya kecurangan akuntansi.

\section{Kesesuaian Kompensasi (X2)}

Kompensasi (Amalia 2015) menjelaskan kompensasi adalah total seluruh imbalan yang diterima para pegawai sebagai pengganti jasa yang telah mereka berikan. Sihotang (2007) Kompensasi adalah pengaturan keseluruhan pemberian balas jasa begi pegawai dan para atasan baik berupa finansial maupun barang dan jasa pelayanan yang diterima oleh setiap pegawai. (Pangabean 2004) Kompensasi dapat di defenisikan sebagai setiap bentuk penghargaan yang diberikan kepada pegawai sebagai balas jasa atas kontribusi yang mereka berikan.

Dengan kompensasi yang sesuai, kecurangan akuntansi dapat berkurang.Individu diharapkan telah mendapatkan kepuasan dari kompensasi tersebut dan tidak melakukan perilaku curang dalam akuntansi untuk memaksimalkan keuntungan pribadi.

\section{Variabel Moderasi \\ Budaya Etis Organisasi (X6)}

Budaya etis merupakan faktor yang paling kritis dalam organisasi.Efektivitas dalam organisasi dapat ditingkatkan dengan menciptakan budaya yang kuat, yang dapat digunakan untuk mencapai tujuan organisasi. Organisasi yang berbudaya kuat akan memiliki ciri khas tertentu sehingga dapat memberikan daya tarik bagi individu untuk bergabung.Variabel budaya etis organisasi diukur dengan instrument yang dikembangkan oleh Aisah Fachrunisa..

\section{Metode Analisis Data}

Analisis Regresi Linear Berganda

Untuk menguji hipotesis digunakan alat analisis regresi berganda, dengan alasan bahwa alat ini dapat digunakan sebagai model prediksi terhadap variabel dependen dengan beberapa variabel independen. Uji hipotesis tersebut akan dilakukan dengan program SPSS 17. Untuk itu diformulasikan model regresi berganda sebagai berikut : 


$\begin{array}{lll} & \mathbf{Y}=\boldsymbol{\alpha}+\boldsymbol{\beta}_{\mathbf{1}} \mathbf{X}_{\mathbf{1}}+\boldsymbol{\beta}_{\mathbf{2}} \mathbf{X}_{\mathbf{2}}+\boldsymbol{\beta}_{\mathbf{3}} \mathbf{X}_{\mathbf{3}}+\mathbf{e} \\ \text { Keterangan: } & \\ \mathrm{Y} \quad= & \text { Kecenderungan kecurangan akuntansi } \\ \mathrm{X} 1= & \text { Asimentri Informasi } \\ \mathrm{X} 2= & \text { Ketaatan aturan akuntansi } \\ \mathrm{X} 3= & \text { Kesesuaian kompensasi } \\ \mathrm{A} & = & \text { Konstanta } \\ \beta & = & \text { Koefisien arah regresi } \\ \mathrm{e} & = & \text { Error }\end{array}$

Untuk menguji pengaruh Budaya organisasi sebagai pemoderasi, maka akan digunakan Multiple Regression Analysis (Ghozali, 2014)

$$
\begin{aligned}
& Y=\alpha+\beta_{1} X_{1}+\beta_{2} Z_{1}+e \\
& Y=\alpha+\beta_{1} X_{1}+\beta_{2} Z_{1}+\beta_{3} X_{1} * Z_{1}+e \\
& Y=\alpha+\beta_{1} X_{2}+\beta_{2} Z_{1}+e \\
& Y=\alpha+\beta_{1} X_{2}+\beta_{2} Z_{1}+\beta_{3} X_{2} * Z_{1}+e \\
& Y=\alpha+\beta_{1} X_{3}+\beta_{2} Z_{1}+e \\
& Y=\alpha+\beta_{1} X_{3}+\beta_{2} Z_{1}+\beta_{3} X_{3} * Z_{1}+e
\end{aligned}
$$

\section{Uji Hipotesis}

Sebelum melakukan pengujian hipotesis yang diajukan dalam penelitian ini, maka terlebih dahulu perlu dilakukan pengujian model. Pengolahan data penelitian ini menggunakan bantuan analisis regresi berganda (multiple regression) dengan bantuan SPSS (statistical product service solution) version 17.

\section{HASIL DAN PEMBAHASAN}

\section{Pengertian kecurangan}

Kecurangan adalah suatu penyimpagan dan perbuatan melanggar hukum (illegal act),yang dilakukan dengan sengaja untuk tujuan tertentu misalnya menipu atau memberikan gambaran keliru (mislead) kepada pihak-pihak lain, yang dilakukan oleh orang-orang baik dalam maupun luar organisasi.

Kecurangan dirancang untuk memanfaatkan peluang-peluang secara tidak jujur,yang secara langsung maupun tidak langsung merugikan pihak lain (Nia Rahmahyanti 2017). Dalam Black's Law Distionary dijelaskan bahwa kecurangan akuntansi adalah istilah umum, mencakup berbagai ragam alat seseorang individual, untuk memperoleh manfaat terhadap pihak lain dengan penyajian yang palsu.

\section{Jenis-jenis kecurangan \\ Association of Certified Fraud Examinations (ACFE-2000) mengkategorikan kecurangan dalam tiga kelompok sebagai berikut:}

Kecurangan Laporan Keuangan (Financial Statement Fraud), Kecurangan ini dapat dibagi dalam beberapa kategori menurut singleton dalam Devi (2011):

1. Timing difference (imporer treatment of sales); bentuk kecurangan laporan keuangan dengan mencatat waktu transaksi yang berbeda atau lebih awal dengan waktu transaksi yang sebenarnya, misalnya mencatat transaksi penjualan lebih awal dari transaksi sebenarnya.

2. Fictious revenues; adalah bentuk laporan keuangan dengan menciptakan pendapatan yang sebenarnya tidak pernah terjadi (fiktif).

3. Cancealed liabilities and expenses; adalah bentuk kecurangan laporan keuangan dengan menyembunyikan kewajiban-kewajiban perusahaan, sehingga laporan keuangan terlihat bagus.

4. Imporer disclosure; adalah bentuk kecurangan perusahaan yang tidak melakukan pengungkapan atas laporan keuangan secara cukup dengan maksud untuk menyembunyikan kecurangankecurangan yang terjadi di perusahaan, sehingga pembaca laporan keuangan tidak mengetahui keadaan yang sebenarnya terjadi di perusahaan.

5. Imporer asset valuation; adalah bentuk kecurangan laporan keuangan dengan melakukan penilaian yang tidak wajar atau tidak sesuai prinsip akuntansi berlaku umum atas aset perusahaan dengan tujuan untuk meningkatkan pendapatan dan menurunkan biaya. 
Penyalahgunaan aset ( Asset Misappropiation), Penyalahgunaan aset dapat digolongkan dalam:

1. Kecurangan kas (cash fraud); yang termasuk kecurangan kas adalah pencurian kas dan pengeluaranpengeluaran secara curang seperti pemalsuan cek.

2. Kecurangan atas persediaan dan aset lainnya (fraud of inventory and all other asset); adalah kecurangan berupa pencurian dan pemakaian untuk kepentingan pribadi terhadap persediaan atau aset lainnya.

Korupsi, Korupsi terbagi atas:

1. Pertentangan kepentingan (conflict of interest); pertentangan kepentingan terjadi ketika karyawan, manajer dan eksekutif perusahaan memiliki kepentingan pribadi terhadap transaksi, yang mengakibatkan dampak kurang baik terhadap perusahaan. Pertentanggan kepentingan termasuk ke dalam tiga kategori yaitu, perencanaan penjualan, rencana pembelian dan rencana lainnya.

2. Suap (bribery); adalah penawaran, pemberian, penerimaan atau permohonan sesuatu dengan tujuan untuk mempengaruhi pembuat keputusan dalam membuat keputusan bisnis.

3. Pemberian illegal (illegal gratuity); pemberian illegal hampir sama dengan suap tetapi pemberian illegal disini bukan untuk mempengaruhi keputusan bisnis, ini hanya sebuah permainan. Orang yang memiliki pengaruh yang dia berikan dalam negosiasi atau kesepakatan bisnis. Hadiah diberikan setelah kesepakatan selesai.

4. Pemerasan secara ekonomi (economic extortion); pada dasarnya pemerasan secara ekonomi lawan dari suap. Penjual menawarkan memberi suap atau hadiah kepada pembeli yang memesan produk dari perusahaan.

\section{Kecenderungan Kecurangan Akuntansi}

Dalam Kamus Besar Bahasa Indonesia (KBBI), Kecenderungan mempunyai arti kecondongan (hati) atau kesudian atau keinginan (kesukaan). Kecurangan (fraud) dapat diartikan sebagai bentuk penipuan yang sengaja dilakukan sehingga dapat menimbulkan kerugian tanpa disadari oleh pihak yang dirugikan tersebut dan memberikan keuntungan bagi pelaku ( Zainal 2013).

Kecenderungan kecurangan akuntansi (KKA) adalah keinginan untuk melakukan segala sesuatu untuk memoeroleh keuntungan dengan cara yang tidak jujur seperti menutupi kebenaran, penipuan, manipulasi, kelicikan atau mengelabui yang dapat berupa salah saji laporan keuangan, korupsi dan penyalahgunaan asset.

\section{Asimetri Informasi}

Salah satu kendala yang akan muncul antara principal dan agent adalah adanya asimetri informasi. Asimetri informasi ini timbul karena principal tidak memiliki informasi yang cukup tentang kinerja agent dan agent memiliki lebih banyak informasi mengenai perusahaan secara keseluruhan (Nasution dan Doddy, 2007).Asimetri informasi yang terjadi antara principal dan agent mendorong agent untuk menyajikan informasi yang tidak sebenarnya, terutama jika informasi tersebut berkaitan dengan pengukuran kinerja agent.Hal ini memacu agent unutk memikirkan bagaimana angka akuntansi dapat digunakan sebagai sarana untuk memaksimalkan kepentingannya.

Asimetri informasi disebabkan oleh permasalahan keagenan yang terjadi bila prinsipal merasa kesulitan untuk menelusuri apa yang sebenarnya dilakukan oleh agen. Selanjutnya asimetri informasi merupakan suatu keadaan dimana agent memiliki akses informasi yang tidak dimiliki oleh pihak principal. Asimetri informasi muncul ketika agent lebih mengenal informasi internal dan prospek dimasa yang akan datang dibandingkan principal dan stake holder lainnya. Asimetri informasi merupakan keadaan dimana pihak dalam perusahaan mengetahui informasi yang lebih baik dibanding pihak luar perusahaan (stakeholder). Jika terjadi kesenjangan informasi antara pihak pengguna dan pihak pengelola, maka akan membuka peluang bagi pihak pengelola dana untuk melakukan kecurangan. Jadi dalam penelitian ini, opportunity dalam teori fraud triangle diproksikan dengan persepsi mengenai penegakan peraturan , keefektifan pengendalian internal, dan asimetri informasi. Rahmawati (2012), terdapat dua macam asimetri informasi, yaitu:

1. Adverse selection, yaitu bahwa para manajer serta orang-orang dalam lainnya biasanya mengetahui lebih banyak informasi tentang keadaan dan prospek perusahaan dibandingkan investor pihak luar. Dan fakta yang mungkin dapat mempengaruhi keputusan yang akan diambil oleh pemegang saham tersebut tidak disampaikan informasinya kepada pemegang saham.

2. Moral hazard, yaitu bahwa kegiatan yang dilakukan oleh seorang manajer tidak seluruhnya diketahui oleh pemegang saham maupun pemberi pinjaman. Sehingga manajer dapat melakukan tindakan diluar pengetahuan pemegang saham dengan melanggar kontrak yang sebenarnya secara etika atau norma mungkin tidak layak dilakukan. 


\section{Ketaatan aturan Akuntansi}

Ketaatan aturan akuntansi juga merupakan salah satu faktor yang mempengaruhi kecenderungan kecurangan akuntansi (bartenputra 2016).Ketaatan aturan akuntansi dipandang sebagai tingkat kesesuaian prosedur pengelolaan aset organisasi, pelaksanaan prosedur akuntansi, dan penyajian laporan keuangan beserta semua bukti pendukungnya, dengan aturan yang ditentukan oleh BPK dan/atau SAP (PP RI Nomor 24/2005). Suatu instansi atau lembaga akan melakukan tindakan kecurangan karena mereka tidak berpedoman pada aturan akuntansi yang berlaku.

Faktor yang menyebabkan maraknya tindak kecurangan akuntansi di Indonesia adalah ketaatan aturan akuntansi. Suatu instansi atau lembaga akan melakukan tindakan kecurangan karena mereka tidak berpedoman pada aturan akuntansi yang berlaku. Fenomena ini terlihat pada kasus yang ditemukan oleh Badan Pemeriksa Keuangan (BPK) yang menyebutkan bahwa hasil pemeriksaan terhadap 662 objek pemeriksaan terdapat sebanyak 3.452 kasus senilai $\mathrm{Rp}$ 9,24 triliun yang berdampak finansial yang merupakan temuan ketidakpatuhan terhadap ketentuan perundang-undangan yang mengakibatkan kerugian Negara, potensi kerugian Negara dan kekurangan penerimaan (shinta devi).

Ketaatan terhadap aturan akuntansi merupakan suatu kewajiban dalam organisasi karena apabila laporan keuangan yang dibuat tidak sesuai atau tanpa mengikuti aturan akuntansi yang berlaku maka keadaan tersebut dapat menumbuhkan perilaku tidak etis dan memicu terjadinya kecurangan akuntansi.

\section{Kesesuaian Kompensasi}

Kompensasi (Amalia 2015) menjelaskan kompensasi adalah total seluruh imbalan yang diterima para pegawai sebagai pengganti jasa yang telah mereka berikan. Sihotang (2007) Kompensasi adalah pengaturan keseluruhan pemberian balas jasa begi pegawai dan para atasan baik berupa finansial maupun barang dan jasa pelayanan yang diterima oleh setiap pegawai.

Dengan kompensasi yang sesuai, kecurangan akuntansi dapat berkurang.Individu diharapkan telah mendapatkan kepuasan dari kompensasi tersebut dan tidak melakukan perilaku curang dalam akuntansi untuk memaksimalkan keuntungan pribadi.(Rahmawati 2012), fungsi kompensasi diantaranya adalah :

1. Pemberian kompensasi dapat menjadikan penggunaan sumber daya manusia lebih efisien dan efektif. Semakin banyak karyawan yang diberi kompensasi yang tinggi berarti semakin banyak karyawannya yang berprestasi tinggi. Banyaknya karyawan yang berprestasi tinggi akan mengurangi pengeluaran biaya untuk kerja-kerja yang tidak perlu yang diakibatkan oleh kurang efisien dan efektifitasnya kerja.

2. Mendorong stabilitas dan pertumbuhan ekonomi. Sistem pemberian kompensasi yang baik secara langsung dapat membantu stabilitas organisasi dan secara tidak langsung ikut andil dalam mendorong stabilitas dan pertumbuhan ekonomi. Sebaliknya pemberian kompensasi yang kurang baik dapat menyebabkan gejolak di kalangan karyawan akibat ketidakpuasan, sehingga ketidakpuasan ini akan menimbulkan kerawanan ekonomi. Kesesuaian dapat didefenisikan sebagai "keselarasan", kecocokan" (Rahmahyanti 2017). Kesesuaian kompensasi adalah keseluruhan balas jasa yang diterima oleh pegawai sebagai akibat dari pelaksanaan di organisasi dalam bentuk uang atau lainnya (Rahmahyanti 2017).

\section{Budaya etis organisasi}

Budaya etis merupakan faktor yang paling kritis dalam organisasi.Efektivitas dalam organisasi dapat ditingkatkan dengan menciptakan budaya yang kuat, yang dapat digunakan untuk mencapai tujuan organisasi. Organisasi yang berbudaya kuat akan memiliki ciri khas tertentu sehingga dapat memberikan daya tarik bagi individu untuk bergabung.

Nilai-nilai dan keyakinan yang berkembang dalam organisasi merupakan dasar adanya budaya organisasi.Nilai-nilai ini berperan penting dalam mempengaruhi perilaku etis individu dalam organisasi (Kinicki dan Kreitner, 2003). Nilainilai tersebut memiliki lima komponen yakni (1) nilai adalah konsep atau keyakinan, (2) nilai untuk mencapai perilaku yang diinginkan, (3) nilai melebihi situasi/objek, (4) nilai memandu pemilihan atau evaluasi perilaku dan peristiwa, dan (5) nilai diperoleh melalui tingkat kepentingannya. (Fakhri 2003) nilai-nilai organisasi dapat berbentuk elite, meritocratic, leadership, dan collegialdimana nilai-nilai organisasi ini cenderung stabil, tidak ada satupun sistem nilai yang terbaik (semuanya saling melengkapi).

\section{Karakteristik Responden}

Populasi yang digunakan dalam penelitian ini adalah seluruh pegawai yang bekerja pada seluruh OPD yang ada di kabupaten Indragiri Hulu. Dari populasi tersebut diambil sampel yang terdiri dari satu kabag keuangan dan dua staf akuntansi. Penelitian ini menggunakan kuesioner dalam pengumpulan data, di mana penyebarannya dilakukan secara langsung (personally administred quesionnaries). personally 
administred quesionnaries yaitu peneliti melakukan pengambilan data dengan mendatangi secara langsung tiap-tiap OPD yang ada di kabupaten Indragiri Hulu. Dari 90 kuesioner, jumlah kuesioner yang kembali berjumlah 84 kuesioner.

\section{Hasil Pengujian Hipotesis}

Tabel 1. Hasil Uji Regresi Hipotesis 1,2 dan 3

Coefficients $^{\mathrm{a}}$

\begin{tabular}{|c|c|c|c|c|c|c|}
\hline \multirow{2}{*}{\multicolumn{2}{|c|}{ Model }} & \multicolumn{2}{|c|}{ Unstandardized Coefficients } & \multirow{2}{*}{$\begin{array}{c}\begin{array}{c}\text { Standardized } \\
\text { Coefficients }\end{array} \\
\text { Beta } \\
\end{array}$} & \multirow[b]{2}{*}{$\mathrm{t}$} & \multirow[b]{2}{*}{ Sig. } \\
\hline & & $\mathrm{B}$ & Std. Error & & & \\
\hline 1 & (Constant) & 19.200 & 6.114 & & 3.141 & .002 \\
\hline & Asim & .605 & .156 & .408 & 3.888 & .000 \\
\hline & ATUR & -.170 & .130 & -.138 & -1.310 & .194 \\
\hline & KOMP & .197 & .101 & .206 & 1.950 & .055 \\
\hline
\end{tabular}

a. Dependent Variable: KECUR

\section{Hasil Pengujian Hipotesis 1}

Tabel diatas dapat dilihat bahwa variabel Asimetri Informasi berpengaruh terhadap Kecenderungan Kecurangan Akuntansi. Hal ini dibuktikan dengan tingkat signifikansi sebesar 0,000 yang lebih kecil dari 0,005. Dari hasil ini dapat ditarik kesimpulan nahwa semakin besar Asimetri Informasi yang terjadi akan menyebabkan terjadinya kecenderungan kecurangan Akuntansi. Hal ini sesuai dengan penelitian yang dihasilkan oleh Aranta (2013) yang menemukan bahwa asimetri informasi berpengaruh terhadap kecenderungan kecurangan akuntansi.

\section{Hasil Penggujian Hipotesis 2}

Tabel diatas dapat dilihat bahwa variabel Ketaatan Aturan Akuntansi tidak berpengaruh terhadap Kecenderungan Kecurangan Akuntansi. Hal ini dibuktikan dengan tingkat signifikansi sebesar 0,194 yang lebih besarl dari 0,005. Dari hasil ini dapat ditarik kesimpulan bahwa variabel Ketaatan Aturan Akuntansi tidak menyebabkan terjadi atau tidak terjadinya kecenderungan kecurangan Akuntansi. Hal ini dapat dikarenakan bahwa ketaatan kepada aturan akuntansi hanya merupakan formalitas kewajiban yang harus diikuti sehingga keberadaannya tidak menyebabkan terjadi atau tidak terjadinya kecurangan akuntansi. Hal ini sesuai dengan penelitian yang dihasilkan oleh Aranta (2013) yang menemukan bahwa asimetri informasi berpengaruh terhadap kecenderungan kecurangan akuntansi.

\section{Hasil Pengujian Hipotesis 3}

Tabel diatas dapat dilihat bahwa variabel Kesesuaian kompensasi tidak berpengaruh terhadap Kecenderungan Kecurangan Akuntansi. Hal ini dibuktikan dengan tingkat signifikansi sebesar 0,055 yang lebih besar dari 0,005. Dari hasil ini dapat ditarik kesimpulan bahwa walaupun kompensasictelah sesuai tidak berpengaruh terhadap kecilnya kemungkinan terjadinya kecenderungan kecurangan akuntansi. Hasil penelitian ini tidak sejalan dengan penelitian yang dilakukan oleh Devi Ervina dkk (2016) bahwa kesesuaian kompensasi berpengaruh terhadap kecenderungan kecurangan akuntansi. Namun konsisten dengan penelitian yang dilakukan oleh Adrian bartenputra (2016) yang menemukan bahwa kesesuaian kompensasi tidak berpengaruh terhadap kecenderungan kecurangan akuntansi. 


\section{Hasil Pengujian Hipotesis Moderasi pertama}

Tabel 2. Hasil Uji MRA Hipotesis 4

Coefficients $^{\mathrm{a}}$

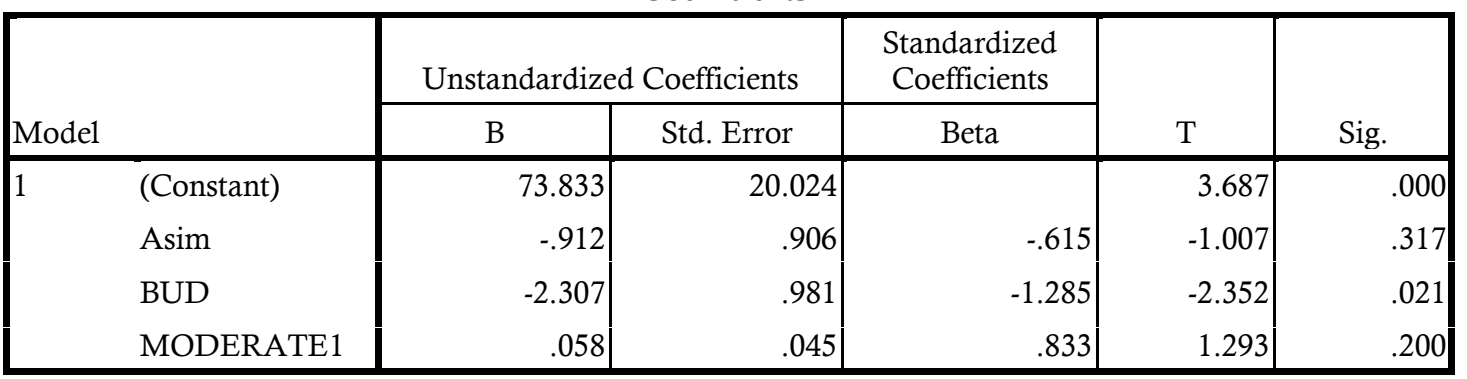

a. Dependent Variable: KECUR

Tabel 2 diatas dapat dilihat bahwa vaibel Budaya Etis Organisasi tidak dapat memoderasi pengaruh Asimetri Informasi terhadap Kecenderungan kecurangan akuntansi. Hal ini dapat dibuktikan dengan tingkat signifikansi 0,200 yang lebih besar dari 0,05 . Hasil ini menunjukkan bahwa variabel Budaya etis organisasi tidak dapat memperlemah pengaruh yang disebabkan oleh ketidaksamaan informasi yang dapat menyebabkan terjadinya kecenderungan kecurangan akuntansi.

\section{Hasil Pengujian hipotesis Moderasi kedua}

Tabel 3. Hasil Uji MRA hipotesis 5

Coefficients $^{\mathrm{a}}$

\begin{tabular}{|c|c|c|c|c|c|c|}
\hline \multirow{2}{*}{\multicolumn{2}{|c|}{ Model }} & \multicolumn{2}{|c|}{ Unstandardized Coefficients } & \multirow{2}{*}{$\begin{array}{c}\begin{array}{c}\text { Standardized } \\
\text { Coefficients }\end{array} \\
\text { Beta }\end{array}$} & \multirow[b]{2}{*}{$\mathrm{T}$} & \multirow[b]{2}{*}{ Sig. } \\
\hline & & B & Std. Error & & & \\
\hline \multirow[t]{4}{*}{1} & (Constant) & 44.737 & 16.349 & & 2.736 & .008 \\
\hline & ATUR & .469 & .678 & .381 & .692 & .491 \\
\hline & BUD & -.614 & .880 & -.342 & -.698 & .487 \\
\hline & MODERATE2 & -.024 & .036 & -.548 & -.657 & .513 \\
\hline
\end{tabular}

a. Dependent Variable: KECUR

Tabel diatas dapat dilihat bahwa variabel Budaya Etis Organisasi tidak dapat memoderasi pengaruh Ketaatan Aturan Akuntansi terhadap Kecenderungan kecurangan akuntansi. Hal ini dapat dibuktikan dengan tingkat signifikansi 0,513 yang lebih besar dari 0,05 . Hasil ini menunjukkan bahwa variabel Budaya etis organisasi tidak dapat memperkuat pengaruh yang disebabkan ketaatan terhadap aturan akuntansi yang dapat menyebabkan kecilnya kemungkinan terjadinya kecenderungan kecurangan akuntansi.

\section{Hasil pengujian hipotesis Moderasi ketiga}

Tabel 4. Hasil uji MRA Hipotesis 6

Coefficients $^{\mathrm{a}}$

\begin{tabular}{|c|c|c|c|c|c|c|}
\hline \multirow{2}{*}{\multicolumn{2}{|c|}{ Model }} & \multicolumn{2}{|c|}{ Unstandardized Coefficients } & \multirow{2}{*}{$\begin{array}{c}\begin{array}{c}\text { Standardized } \\
\text { Coefficients }\end{array} \\
\text { Beta }\end{array}$} & \multirow[b]{2}{*}{$\mathrm{T}$} & \multirow[b]{2}{*}{ Sig. } \\
\hline & & B & Std. Error & & & \\
\hline \multirow[t]{4}{*}{1} & (Constant) & 27.412 & 23.888 & & 1.148 & .255 \\
\hline & KOMP & .858 & .721 & .899 & 1.191 & .237 \\
\hline & BUD & .110 & 1.204 & .061 & .091 & .928 \\
\hline & MODERATE3 & -.039 & .036 & -1.098 & -1.075 & .286 \\
\hline
\end{tabular}

a. Dependent Variable: KECUR

Tabel diatas dapat dilihat bahwa variabel Budaya Etis Organisasi tidak dapat memoderasi pengaruh Kesesuaian kompensasi terhadap kecenderungan kecurangan akuntansi. Hal ini dapat dibuktikan dengan tingkat signifikansi 0,286 yang lebih besar dari 0,05. Hasil ini menunjukkan bahwa 
variabel Budaya etis organisasi tidak memperkuat pengaruh yang disebabkan kesesuaian kompensasi yang dapat menyebabkan kecilnya kemungkinan terjadinya kecenderungan kecurangan akuntansi.

\section{KESIMPULAN}

Dari hasil yang telah diperoleh dari penelitian ini dapat ditarik beberapa kesimpulan sebagai berikut: 1) Asimetri Informasi berpangaruh terhadap Kecenderungan kecurangan akuntansi. Hasil ini mengandung arti bahwa ketidaksamaan informasi dapat menyebabkan tingginya kecenderungan kecurangan akuntansi. 2) Ketaatan aturan akuntansi tidak berpengaruh terhadap Kecenderungan kecurangan akuntansi. Hasil penelitian ini menunjukkan bahwa taatnya terhadap aturan akuntansi sudah merupakan kewajiban sehinngga tidak ada pengaruhnya terhadap kecenderungan kecurangan akuntansi. 3) Kesesuaian kompensasi tidak berpengaruh terhadap Kecenderungan kecurangan akuntansi. Hal ini mengandung arti bahwa timggi atau rendahnya kompensasi yang diberikan tidak ada pengaruhnya terhadap tinggi atau rendahnya kecenderungan kecurangan akuntansi. 4) Hasil penelitian menunjukkan bahwa variabel Budaya etis organisasi tidak memoderasi pengaruh asimetri informasi, ketaatan aturan akuntansi dan kesesuaian kompensasi terhadap kecenderungan kecurangan akuntansi.

\section{UCAPAN TERIMAKASIH}

Terimakasih kepada semua pihak yang telah membantu penelitian ini.

\section{DAFTAR PUSTAKA}

Adrian Bartenputra. (2016). Pengaruh Kesesuaian Kompensasi, Ketaatan Aturan Akuntansi Dan Asimetri Informasi Terhadap Kecenderungan Kecurangan Akuntansi.Fakultas Ekonomi. Universitas Negeri Padang.

Aisah Fachrunisa. (2015). Pengaruh Keefektifan Pengendalian Internal, Keadilan Distributif, Keadilan Prosedural, Dan Budaya Etis Organisasi Terhadap Kecenderungan Kecurangan (Fraud) Akuntansi (Studi Empiris Pada Skpd Kabupaten Kampar).Fakultas Ekonomi.Universitas Riau.

Amalia, Kamaliah, Rahmiati. (2015). Pengaruh Keefektifan Pengendalian Internal, Kesesuaian Kompensasi, Moralitas Aparat Dan Asimetri Informasi Terhadap Kecenderungan Kecurangan Akuntansi. Jurnal Online Fakultas Ekonomi. Universitas Riau

Aranta Zulia,Petra. (2013). Pengaruh Moralitas Aparat Dan Asimetri Informasi Terhadap Kecenderungan Kecurangan Akuntansi.Universitas Negeri Padang.

Christofel, Rendy. (2010). Moderasi Pengendalian Internal Pada Hubungan Pengaruh Keadilan Organisasional Terhadap Tingkat Kecurangan (Fraud).Skripsi.Semarang : Fakultas Ekonomi UNDIP.

Hariandja, Marihot Tua Effendi. (2005). Manajemen Sumber Daya Manusia : Pengadaan, Pengembangan, Pengkompensasian, Dan Peningkatan Produktivitas Pegawai.Cetakan Ketiga.Grasindo. Jakarta.

IAPI.Standar Professional Akuntan Public (PSAP), 31 Maret 2011. Salemba Empat. Jakarta.

Indriastuti, Agusdin, Animah. (2016). Analisis Pengaruh Asimetri Informasi,Pengendalian Internal, Persepsi Kesesuaian Kompensasi,Moralitas Individu, Dan Ketaatan Aturan Akuntansi.Fakultas Ekonomi.Universitas Mataram.

Kohlberg,Lawrance. (1995). Tahapan-Tahapan Perkembamgan Moral.Kanisius: Yogyakarta.

Kreitner, Robert Dan Angelo Kinicki. (2003). Perilaku Organisasi (Organizational Behaviour). Penerbit: Salemba Empat. Jakarta.

Kusuma Yadna,Kadek Sinarwati,Adi Yuniarta. (2017). Pengaruh Moralitas Individu, Efektivitas Sistem Pengendalian Internal, Dan Ketaatan Aturan Akuntansi Terhadap Kecenderungan Kecurangan.Jurnal.Fakultas Ekonomi. Universitas Negeri Padang. 
Kusumastuti Ratri, Nur. (2012). Analisis Faktor-Faktor Yang Berpengaruh Terhadap Kecenderungan Kecurangan Akuntansi Dengan Perlaku Tidak Etis Sebagai Variabel Intervening.Skripsi.Universitas Diponegoro.

Monday, Wayne R. (2008). Manajemen Sumber Daya Manusia.Jakarta : Erlangga.

Peraturan Pemerintah No.60 Tahun (2008) Tentang Sistem Pengendalian Internal Pemerintah (SPIP).

Rahmahyanti, Hardi, Kurnia. (2017). Pengaruh Sistem Pengendalian Internal, Kesesuaian Kompensasi Dan Asimetri Informasi Terhadap Kecenderungan Kecurangan Akuntansi.Skripsi.Fakultas Ekonomi.Universitas Riau.

Rahmawati, Ardiana Peni. (2012). Analisis Faktor Internal Dan Moralitas Manajemen Terhadap Kecenderungan Kecurangan Akuntansi: Skripsi. Universitas Diponegoro.

Scoot,William R. (2003). Financial Accounting Theory.New Jersey : Prentice Hall Inc.

Setiawan Dan Helmayunita. (2017). Pengaruh Pengendalian Internal, Moralitas Individu Terhadap Kecenderungan Kecurangan Akuntansi: Studi Eksperimen Pada Konteks Pemerintahan Daerah.

Sugiono. (2012). Metode Penelitian Bisnis.Cetakan Keenam Belas.Bandung:Alfabeta.

Widiutami,Sulindawati, Dan Atmadja. (2017). Pengaruh Efektivitas Pengendalian Internal, Ketaatan Aturan Akuntansi, Dan Komitmen Organisasi Terhadap Kecenderungan Kecurangan (Fraud) Akuntansi (Studi Empiris Pada Lembaga Perkreditan Desa Di Kabupaten Buleleng). Universitas Pendidikang Ganesha Singaraja, Indonesia.

Wilopo. (2006). Analisis Faktor- Faktor Yang Berpengaruh Terhadap Kecenderungan Kecurangan Akuntansi: Studi Pada Perusahaan Public Dan Badan Usaha Milik Negara. SNA IX : Padang.

Zainal Risky. (2013). Pengaruh Efektifitas Pengendalian Internal, Asimetri Informsi, Dan Kesesuaian Kompensasi Terhadap Kecenderungan Kecurangan Akuntansi.Universitas Negeri Padang.

Zilmi, Rian Putra. (2013). Pengaruh Kesesuaian Kompensasi, Asimetri Informasi Dan Moralitas Terhadap Kecenderungan Kecurangan Akuntansi.Jurnal.Fakultas Ekonomi.UNP. 